\title{
18
}

\section{World Bank Intervention and Introduction of Social Health Insurance in Albania}

\section{Ertila Druga}

\section{Introduction}

National factors alone cannot explain the dynamics of social policy development. International influences in the form of ideas and expertise may also shape domestic public policy (Obinger et al. 2013), and International Organisations (IOs) are key actors in the process. This chapter explores this claim by investigating the role of the World Bank (WB) in the making of Social Health Insurance (SHI) in Albania. The case demonstrates the interaction between an International Organisation and a nation state as well as the impact of vertical interrelations in the early post-communist Albanian healthcare reforms.

Albania adopted the law on Social Health Insurance in October 1994 (Albanian Parliament 1994), being the only country in Central and Eastern Europe (CEE) with no prior experience with a contributory system. The other CEE countries had experienced some form of SHI in the

\section{E. Druga $(\bowtie)$}

University of Bremen, Bremen, Germany

e-mail: ertila.druga@uni-bremen.de 
period before the Second World War. Coming out of the communist state period, Albania was also the more isolated and the poorest country in the region; that was the reason for the World Bank's engagement in assisting the country's efforts for its future economic and social development. In drafting the strategy for the Albanian healthcare sector, the introduction of SHI brought about disagreement and controversies between the Albanian government and the World Bank. The government had put it forward on the healthcare agenda for reform (see Kaminska et al. 2021) and insisted on keeping it despite the Bank's advice for its later adoption. However, this chapter does not deal with the rationale behind the decision to adopt SHI in Albania. The aim here is to explore more the content of the advice and expertise provided by the Bank and accepted by the government during the formulation of SHI law. The research covers the period 1991 to 1994 , and the analysis is supported by empirical data drawn from World Bank documents, Albanian parliamentary sessions, and expert interviews.

Which recommendations did the Bank make for the future of financing health in Albania, and how did they develop during the process? The case shows that the Bank strongly advised for keeping the role of the state in financing health, at least during the early years of transition. This finding contrasts with the view of the Bank which is often judged and looked at through "neoliberal glasses" (Babb and Kentikelenis 2018; Navarro 2020). Even though the WB could not influence the decision of (not) introducing SHI, its expertise was useful during the formulation of the draft legislation. Therefore, this chapter contributes to enriching the scholarship on the role of the World Bank in post-communist reforms in CEE. Moreover, it adds to healthcare policy research during the transition period in the countries of CEE and, particularly, in Albania.

\section{The World Bank's Preference and Prescription on Social Health Insurance in CEE}

Two reports by the World Bank, advocating "market-driven" or "neoliberal" ideas have served as the blueprint for transitional healthcare reforms in low and middle-income countries. In 1987, Financing Health Services 
in Developing Countries: An Agenda for Reform proposed an alternative approach to financing healthcare in developing countries through four policies: (1) introducing user fees in health; (2) providing insurance or other risk coverage, and encouraging well-designed health insurance programmes to help mobilise resources for health; (3) using non-government resources effectively; and (4) decentralising government healthcare services (World Bank 1987, 6). It was, however, the 1993 World Development Report: Investing in Health, which brought these policies together into a comprehensive approach advocating for market competition to foster service quality, system efficiency, and cost control, with the role of the government more on the regulatory side (World Bank 1993a, 7).

Researchers on the World Bank's position on the introduction of SHI in CEE provide two different accounts of the topic. The first group of researchers represents the Bank as favouring the introduction of SHI in the post-communist countries of the region (Cerami 2006, 69). In their view, the WB considered the introduction of health insurance financing systems to replace general taxation as one of the most important market changes and influenced the decision-making processes through its advisors (Nemec and Kolisnichenko 2006, 24). The second group of scholars (Roberts 2009; Sabbat 2010; Kaminska et al. 2021) provides other pieces of evidence. Roberts (2009, 314-16) states that the Bank's recommendations for the Czech healthcare reform in 1991 urged for the maintenance of many features of the old system and state funding. Even in Poland, he claims that the WB did not recommend market solutions but advocated increased efficiency within a highly centralised system and central budget financing. Sabbat (2010) attests that in Poland "(...) the introduction of health insurance was not dictated nor even promoted by the World Bank, whose experts suggested if anything, caution”. Kaminska et al. (2021) give a more detailed account of the lack of WB influence on the decision to introduce SHI in three post-communist countries: Albania, Poland, and Latvia.

To summarise, there is enough evidence from previous research to indicate first what the WB advised and second that it was unsuccessful in trying to influence the decision of whether SHI should be introduced in a number of countries in the region. This contribution moves the analysis beyond that point and looks at what the WB did next. And what this 
contribution discovers is that the WB continued to be involved and adjusted to the preference of the recipient (Albania) and offered advice (this time accepted) on how to formulate the law.

\section{Historical Background: Albania at the Start of Transition}

Albania was the last communist country in CEE to embark on the road of transition. The inherited healthcare system-the Soviet Semashko type, characterised by centrally planned resource allocation and highly centralised management decisions_-did not differ from those in the other post-communist countries in the region. The quality of care was low, and the system offered few incentives for efficiency and cost control. However, in the early 1990s, distinct backwardness and the extreme isolation of the past combined with the difficulties of transition, such as high inflation, budgetary and external imbalances, and a sharp fall in GDP, projected a negative perspective for the Albanian health sector.

The Labour (ex-Communist) Party government that emerged from the first multiparty elections, held in March 1991, was only short lived. It was forced to resign just five weeks after taking power. The next government, named the Stability Government, was a coalition of technocrats from the Socialists (the Labour Party changed into the Socialist Party), and the other newly established parties: The Democrats, the Republicans, and the Social Democrats. The main objective of this government was the stabilisation of the economy, and it drew up an ambitious reform programme named The Programme for the Transition to a Free Market of the Albanian Economy, which was approved by parliament in October 1991. This programme had listed "the introduction of a social security system" (Pashko 1993, 911) among its main pillars. Regarding the healthcare system, SHI was incepted and already proclaimed in the 1991 election programme of the Democratic Party, and the work on an initial draft law started that same year (Shehu $\left.{ }^{1} 2019\right)$.

\footnotetext{
${ }^{1}$ Minister of Health in Albania (April 1992-January 1994).
} 
Before 1991, Albania had no relationship with the "Western" international financial institutions. The country joined the World Bank Group in October 1991, and shortly after membership approval, a mission on the health sector arrived in the country (October-November 1991). In March 1992, this mission presented "A strategy for the survival and long-term development of the Albanian health system in the context of the larger transformation" to the government. In future health financing, the WB projected, "public budgets will continue to be the primary source of funding for the healthcare system for much of the next ten years" (World Bank 1992, 32). This recommendation brought about a disagreement; the government was insisting on its preference, the introduction of SHI, whereas the World Bank on the argument of a postponed decision. Their dialogue developed (Shehu, 2012), until, in June 1993, the Ministry of Health presented A New Policy for the Healthcare Sector in Albania (mid-term strategy), aiming at "a careful introduction of a scheme of health insurance" (Nuri 2002, 69). Therefore, the work on formulating the draft continued until mid-1994. Then, the new law was approved by the Council of Ministers and on 13 October 1994 by the Albanian parliament.

\section{$4 \quad$ World Bank's Recommendations in Health Financing Reform and the Making of Social Health Insurance in Albania}

The WB was involved in two periods of the policy process: the early stage of setting the agenda for the future healthcare reforms in the country, and the formulation of the law on SHI.

\subsection{The Early Stage of Disagreement}

In late 1991 and early 1992, the Bank's main recommendations aimed at protecting financing resources in the health sector. Considering the 
circumstances, this was of particular importance and the WB strived to warn the government to be aware that attempts to restore fiscal stability in the country-all efforts were towards economic stabilisation-would create a strong pressure "to cut back on all areas of public expenditure" (World Bank 1992, 32). The WB argued that in the light of the missing costs calculations, due to domestic incapability and hard-to-predict estimations because of future insecurities, "a good rule of thumb could be keeping up with the same amount of 4 percent of the GDP2" (World Bank 1992, 32) as planned for health in the previous periods.

As the next step, the WB proposed establishing SHI and developing alternative financing. In the Bank's view, the positive projections for the economy in the following years would increase individuals' incomes and improve prospects for the introduction of SHI. However, the Bank estimated that this period would take several years. Furthermore, until then, the government should take some preliminary steps leading to the development of such a system. The Bank illustrated that these steps would include the establishment of accounting and financial management systems at all health facilities to produce unit cost calculations, and the development of payment/reimbursement schemes and their gradual application in the system to replace the ex-ante budgeting method, while the financing was still public. Lastly, the Bank claimed that until the final step of introducing the contributory scheme, other preconditions should be fulfilled. Income stability resulting from economic growth and development, placing other social insurance schemes (the pension scheme) under control, reaching consensus on contribution schemes as well as good administrative capacities would increase the feasibility of introducing a contributory system in Albania.

\subsection{The Late Stage of Agreement}

During the years 1992 and 1993, the WB concentrated on two main objectives in Albania: macroeconomic stabilisation and pension reform. The reform of pensions and social assistance was particularly challenging,

\footnotetext{
${ }^{2}$ Total health expenditures in 1990 amounted to around eighty-four US \$4 million or twenty-four US \$ per capita (World Bank 1992, 5).
} 
not only because the pension fund was facing bankruptcy due to a near economic breakdown but also because the fund could not shoulder the burden of the unemployed at a time when there was no social assistance system other than the pension system. "The concern of the Bank was that there was a huge pension contribution already, somewhere around 21-22 percent (of the gross wage)" (Goldstein 32020$)$, and together with the other taxes, the total burden would be about 35-40 percent (World Bank 1992, 26). Adding the contribution for health insurance would translate into higher labour costs. The WB had a "bird's-eye view" of parallel reforms planned to be implemented and considered that high labour costs would affect the country's future development strategy.

Once the WB accepted that the government would pursue its idea of immediately introducing SHI, rather than postponing the reform for several years, two main issues featured in the "deal" between the WB and the government on the potential introduction of SHI: the contribution rate and, consequently, the coverage (Shehu 2012, 2019). The government proposed a contribution rate of 7 percent of the gross wage, but the Bank criticised it, advancing the argument that the rate was too high (Shehu 2012). The Bank's efforts were to make sure that the economy could grow sustainably and inclusively and the cost of labour could remain competitive.

So, we (WB) put in place a 2 percent payroll tax (for SHI), and it was supposed to be a dedicated fund for the purchase of drugs, to cover people's pharmaceutical purchases (from) a list of essential drugs. (Goldstein 2020)

The final contribution rate was defined at 3.4 percent of the gross wage, paid half by the employer and half by the employee. The initial draft law envisaged that the SHI would cover all healthcare services (Albanian Parliament 1994). Accordingly, SHI would cover healthcare services at the primary level: family doctor, specialist doctor, and ambulatory care; at the secondary level: specialised outpatient and inpatient care, dental care services for individuals up to eighteen years old, and the

\footnotetext{
${ }^{3}$ World Bank Task Manager in Albania (1993-1995), responsible for the preparation of the Health Services Rehabilitation Project (World Bank 1994) and World Bank Director for Western Balkan countries (2013-2017).
} 
reimbursement of a list of drugs. However, Albania was starting (SHI) from scratch, which meant that extensive preparative work had to be fulfilled, like the calculation of costs (of the healthcare services), the preparation of reimbursement schemes, and the development of administrative capacities. These were precisely the arguments the World Bank presented in its report in 1992, which formed the basis for the Bank's proposal for a later introduction of SHI while appealing for the fulfilment of some "preliminary steps leading to the development" of a health insurance system.

The coverage issue was another problem, as visible in the escalating costs in the newly reintroduced SHI in other countries of the region. After the reintroduction of SHI in the Czech Republic in 1992, healthcare costs, particularly of drugs and hospital services, were increasing fast (Shehu 1994). ${ }^{4}$ Aware of these experiences, the domestic experts in Albania excluded the coverage of the services at the secondary level (hospital) shortly before the law passed through parliament and allowed for the gradual implementation of the system or rather "the scheme", which started in mid-1995. Initially, it covered the costs of a list of essential drugs and soon after that it also covered the service of the family doctors (primary healthcare service). The list of essential drugs received high priority in drafting the law as the price of drugs increased immensely due to price liberalisation and free trade reforms (Albanian Parliament, 1994).

\section{Discussions and Conclusions}

In Albania, the introduction of SHI was domestically ideated, pushed forward, and put onto agenda by domestic actors (Kaminska et al. 2021). The World Bank was not in favour of this choice. However, it adjusted its advice in relation to the wish of the government. Further research is needed to elucidate on why the World Bank did so and how the interaction with the government evolved.

\footnotetext{
${ }^{4}$ In the period 1992-1993, one of the experts of the World Bank in the Social Safety Net project in Albania was the Czech expert, Igor Tomes. He was also involved in drafting the New Social Insurance Act adopted by the Albanian Parliament on May 11, 1993 (World Bank 1993b). In the mid-2000s, he worked for developing the SHI law and extending the coverage to hospital services.
} 
Noticeably, the WB assisted the process and advised the government to adopt a set of technical recommendations. This finding confirms that although the external influence was not able "to determine the policy choice" (Roberts 2009, 314), it did, however, shape policy formulation.

The empirical analysis illustrates the content of the recommendations the WB provided to the government. Consistent with previous research (Roberts 2009; Sabbat 2010), the Bank strongly advised keeping the role of the state in financing health, "at least until more stable economic conditions permit the introduction of a health insurance scheme" (World Bank 1992, 2). On that basis, I may denote that the World Bank is often judged and looked at through "neoliberal glasses", expecting that any idea uttered by the World Bank is neoliberal. What happened in the early stage of the process in Albania shows the contrary.

Finally, this case demonstrates that international influences in the form of technical assistance and expertise may shape domestic public policy (Obinger et al. 2013). The WB could convince the government to adopt a set of technical recommendations related to the contribution rate and the coverage of health services. As a result, by implementing a lower rate, the health insurance contribution rate only slightly affected the cost of labour. Thus, in mid-1995, SHI started "small" in the form of a "scheme" initially covering a list of drugs and the services of the family doctors.

Acknowledgements This chapter is a product of the research conducted in the Collaborative Research Center "Global Dynamics of Social Policy" at the University of Bremen. The centre is funded by the Deutsche Forschungsgemeinschaft (DFG, German Research Foundation)_-project number 374666841-SFB 1342.

\section{References}

Albanian Parliament. 1994. Parliamentary Session-Discussion and Approval of 'Law 7870 on Health Insurance in the Republic of Albania.'

Babb, Sarah L., and Alexander E. Kentikelenis. 2018. International Financial Institutions as Agents of Neoliberalism. In The SAGE Handbook of Neoliberalism, 16-27. https://doi.org/10.4135/9781526416001.n3. 
Cerami, Alfio. 2006. Social Policy in Central and Eastern Europe: The Emergence of a New European Welfare Regime (Vol. 43). Münster: LIT Verlag Münster.

Kaminska, Monika Ewa, Ertila Druga, Liva Stupele, and Ante Malinar. 2021. Changing the Healthcare Financing Paradigm: Domestic Actors and International Organizations in the Agenda Setting for Diffusion of Social Health Insurance in Post-communist Central and Eastern Europe. Social Policy \& Administration 55 (6): 1066-1081. https://doi.org/10.1111/ spol.12724.

Navarro, Vicente. 2020. Neoliberalism, Globalization, and Inequalities: Consequences for Health and Quality of Life. London: Routledge.

Nemec, Juraj, and Natalya Kolisnichenko. 2006. Market-Based Health Care Reforms in Central and Eastern Europe: Lessons after Ten Years of Change. International Review of Administrative Sciences 72 (1): 11-26.

Nuri, Besim. 2002. Albania: Health Care Systems in Transition. In HiT's in European Obversatory on Health Systems and Policies, ed. Ellie Tragakes, 4 (6). Copenhagen: WHO Regional Office for Europe.

Obinger, Herbert, Carina Schmitt, and Peter Starke. 2013. Policy Diffusion and Policy Transfer in Comparative Welfare State Research. Social Policy \& Administration 47 (1): 111-129.

Pashko, Gramoz. 1993. Obstacles to Economic Reform in Albania. Europe-Asia Studies 45 (5): 907-921.

Roberts, Andrew. 2009. The Politics of Healthcare Reform in Postcommunist Europe: The Importance of Access. Journal of Public Policy 29 (3): 305-325. Sabbat, Jolanta. 2010. Rapid Response to 'Poland's Painful Market Reforms'. The BMJ. British Medical Journal Publishing Group 2010; 340. Accessed March 15, 2021. https://www.bmj.com/content/340/bmj.c2837/rapidresponses.

Shehu, Tritan. 1994. Parliamentary Session-Discussion and Approval of Law 7870 On Health Insurance in the Republic of Albania. Tirana, Albania. Albanian Parliament. (1994, October 13).

— 2012. 'Perqasje' Reformat ne Shendetesi, Tritan Shehu (Video File). Accessed March 15, 2021. https://www.youtube.com/ watch?v=VomjsX-bo90\&t $=1809$ s.

World Bank. 1987. Financing Health Services in Developing Countries: An Agenda for Reform. Accessed March 15, 2021. http://documents.worldbank. org/curated/en/458211468158384680/World-development-report-1987. . 1992. Albania: Health Sector Reform during Transition. 10362-AL, (10362-AL): 55. 
. 1993a. World Development Report: Investing in Health. New York: Oxford University.

— 1993b. Albania_Technical Assistance Project for Social Safety Net Development. Washington, DC: World Bank Group.

—. 1994. Albania_Health Services Rehabilitation Project (English). Washington, DC: World Bank Group.

\section{Annex of Interviews}

Goldstein, Ellen. (2020, June 19). Personal Interview (Skype Interview). Shehu, Tritan. (2019, October 8). Personal Interview (Face-to-Face Interview).

Open Access This chapter is licensed under the terms of the Creative Commons Attribution 4.0 International License (http://creativecommons.org/ licenses/by/4.0/), which permits use, sharing, adaptation, distribution and reproduction in any medium or format, as long as you give appropriate credit to the original author(s) and the source, provide a link to the Creative Commons licence and indicate if changes were made.

The images or other third party material in this chapter are included in the chapter's Creative Commons licence, unless indicated otherwise in a credit line to the material. If material is not included in the chapter's Creative Commons licence and your intended use is not permitted by statutory regulation or exceeds the permitted use, you will need to obtain permission directly from the copyright holder.

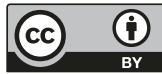

